aid to predictability. ${ }^{20}$ If these pre-licensing statements are to be subjected to immediate judicial review, however, agencies can scarcely be expected to make them freely.

The instant case is a warning that these announcements, though addressed only indirectly to members of the public, and enforceable only on the contingency of an administrative hearing, are nevertheless reviewable if they invite reliance by the ordinary businessman, and this reliance results in irreparable harm.

\title{
RIGHT OF MUNICIPAL CORPORATION TO DISPOSE OF PROPERTY ACQUIRED BY CONDEMNATION*
}

In I9I4, the Sanitary District of Chicago acquired certain land by condemnation under a statute providing, "Such sanitary district may acquire by purchase, condemnation or otherwise, any and all real and personal property, right-of-way and privilege .... that may be required for its corporate purposes .... and when not longer required for such corporate purposes, any such sanitary district may sell .... all such real and personal property, right-of-way, and privilege."'x The condemnation order awarded compensation "for the taking of said fee simple title of said real estate for the corporate purposes of said petitioner and for all other lawful purposes." In I937, the Sanitary District undertook to sell and convey the land to the defendant. Upon a tender of a warranty deed, the defendant declined to accept on the ground that the Sanitary District had only a right-of-way and not the fee simple. The Sanitary District then sued for specific performance of the contract. The defendant argued that the condemnation statute did not authorize the taking of a fee simple and furthermore, that if it did, it was unconstitutional because it would permit the Sanitary District to condemn for a private use in violation of the Illinois Constitution. From a decree for the Sanitary District the defendant appealed. Held: Affirmed. The statute authorized the taking of the fee simple and the statute was not unconstitutional. The Sanitary District had acquired a fee simple which it could convey to the defendant in performance of the executory contract. The Sanitary District of Chicago v. Manasse. ${ }^{2}$

The decision seems sound. The express stipulation in the Illinois Constitution which limits the interest which may be condemned for railroad tracks to an easement ${ }^{3}$ and the omission of a similar limitation in the sections of the constitution and of the statutes applicable to this case would appear to bring the case within the maxim, expressio unius est exclusio alterius.

${ }^{20}$ Administrative Procedure in Government Agencies: Report of the Committee on Administrative Procedure, 77th Cong. Ist Sess., at 26-27 (I94I).

* The Sanitary District of Chicago v. Manasse, 380 Ill. 27, 42 N.E. (2d) 543 (1942).

IIll. Rev. Stat. (r94r) c. 42, $\$ 327$. In a portion of the section which has not been copied the sale of specified tracts without the approval of the Department of Purchases and Construction is prohibited.

${ }^{2} 380$ Ill. 27,42 N. E. (2d) 543 (I942). 3 Ill. Const. art. 2, § I3. 
A more important reason for the conclusion that the Sanitary District had a fee simple is that the devise of an interest which expires when the property ceases to be devoted to public use does not protect owners of property against overzealous or corrupt public officials. The danger that property will be taken for a purpose other than a public use is not great since the courts scrutinize carefully the program in connection with which condemnation is sought. 4 Moreover, the history of the building of the railroads in Illinois does not indicate that the constitutional provision which prohibits the condemnation of a fee for a railroad right-of-way has discouraged the construction of railroads and thus protected the owners of Illinois land against the promoters. ${ }^{5}$

From the point of view of the individual owner, even if the interest taken is limited to an easement or a determinable estate, his loss is usually as great as though the fee simple had been taken because, I) so long as the public use continues, it is not usually feasible for the owner to make any use of the land, and 2) since the date of the termination of the use cannot be fixed more definitely than "when the use ceases," the value of the interest retained is nominal. Consequently the owner should receive, and doubtless does receive in most cases, compensation for an interest which will endure forever. ${ }^{6}$ Should the interest taken expire because the public use is abandoned, the former owner, having been fully compensated, acquires a windfall. Moreover, the inability of the public agency to put the land on the market may well cause the continuance of unsound public enterprises which would otherwise be materially modified or liquidated and the proceeds applied to new projects which were more useful.7

A method which would afford the maximum of protection to owners without unduly limiting the public agencies would be to give the owner whose land has been condemned a right of pre-emption if the property is put on the market. Such a right is given under certain conditions by the English Lands Clauses Consolidation Act, $1845 .{ }^{8}$ But even though a right of pre-emption has not been authorized in Mlinois, the conclusion that the interest of the Sanitary District was a fee simple which might be sold is both desirable and clearly justified by the Illinois Constitution and statutes.

4 Tedens v. The Sanitary District of Chicago, I49 Ill. 87, 36 N. E. I033 (1894).

5 Steam Railways-Miles of Road Owned, by States: 1860 to 1939 , Statistical Abstract of the United States 460 , table 498 (I94r). This table indicates that nearly 8,000 miles of railway lines have been built in Illinois since the adoption of the constitution which reserves the fee in lands condemned for railroad tracks.

${ }^{6}$ In one case it was said that "It is a fair assumption that a condemnation price is always about three times the price which could otherwise be obtained. . ..." U.S. v. Certain Land in Falls Twp., $3^{8}$ F. (2d) rog, rio (r930).

3 This difficulty is noted in the Chicago Bureau of Public Efficiency Report on Excess Condemnation 50 (I9I8). To avoid the difficulty an attempt was made in the Illinois Constitutional Convention of Ig20-Ig22 to eliminate the clause which prohibits the taking of the fee for railroad tracks. Britton, Constitutional Changes in Eminent Domain in Illinois, 2 Ill. L. Bull. 479,506 (I920).

88 \& 9 Vict., c. $18, \$ \S 127-30$ ( 1845$)$. 